\title{
Communication
}

\section{Enzymatic Primary Amination of Benzylic and Allylic C(sp)-H Bonds}

\author{
Zhi-Jun Jia, Shilong Gao, and Frances H. Arnold
}

J. Am. Chem. Soc., Just Accepted Manuscript • DOI: 10.1021/jacs.0c03428 • Publication Date (Web): 25 May 2020

Downloaded from pubs.acs.org on May 26, 2020

\section{Just Accepted}

"Just Accepted" manuscripts have been peer-reviewed and accepted for publication. They are posted online prior to technical editing, formatting for publication and author proofing. The American Chemical Society provides "Just Accepted" as a service to the research community to expedite the dissemination of scientific material as soon as possible after acceptance. "Just Accepted" manuscripts appear in full in PDF format accompanied by an HTML abstract. "Just Accepted" manuscripts have been fully peer reviewed, but should not be considered the official version of record. They are citable by the Digital Object Identifier (DOI®). "Just Accepted" is an optional service offered to authors. Therefore, the "Just Accepted" Web site may not include all articles that will be published in the journal. After a manuscript is technically edited and formatted, it will be removed from the "Just Accepted" Web site and published as an ASAP article. Note that technical editing may introduce minor changes to the manuscript text and/or graphics which could affect content, and all legal disclaimers and ethical guidelines that apply to the journal pertain. ACS cannot be held responsible for errors or consequences arising from the use of information contained in these "Just Accepted" manuscripts. 
Nitrogen is a key component of functional molecules: $80 \%$ of small-molecule drugs contain at least one nitrogen atom. ${ }^{1}$ Particularly privileged are primary amines that serve as essential intermediates in the construction of secondary amines, tertiary amines, and heterocycles. ${ }^{2}$ A plethora of transformations have been developed to introduce the primary amine moiety into organic structures, given its importance as a fundamental functional group. ${ }^{2,3}$ Classical synthesis of primary amines usually relies on manipulation of functional groups, such as reduction of azides or nitriles, reductive amination of carbonyl compounds, ${ }^{4}$ and Buchwald-Hartwig amination of aryl halides. ${ }^{5}$ Although $\mathrm{C}-\mathrm{H}$ functionalization has emerged as a promising strategy that maximizes atom- and step-economy, state-of-the-art methods for amine synthesis typically provide $N$-protected or $N$-substituted products that require additional manipulation to access the corresponding primary amines. ${ }^{6}$ Recently, a few methods have been developed for primary amination of $\mathrm{C}\left(s p^{2}\right)-\mathrm{H}$ bonds, including photoredox catalysis, ${ }^{7}$ electrochemical catalysis, ${ }^{8}$ and the use of other novel amination reagents and metal catalysts. ${ }^{9}$ Primary amination of $\mathrm{C}\left(s p^{3}\right)-\mathrm{H}$ bonds, however, has remained elusive. Biocatalytic approaches have been exploited to selectively introduce primary amine functionalities, as exemplified by transaminases, ${ }^{10}$ but these all require pre-oxidized substrates and do not introduce the amine at a $\mathrm{C}-\mathrm{H}$ bond.

Natural evolution has created diverse enzymes for selective C$\mathrm{H}$ functionalization, ranging from hydroxylation to halogenation, under ambient conditions. ${ }^{11}$ Among these, the direct hydroxylation of $\mathrm{C}\left(s p^{3}\right)-\mathrm{H}$ bonds catalyzed by cytochrome $\mathrm{P} 450$ enzymes (P450s) exemplifies the remarkable ability of enzymes to mediate transformations that are challenging for small-molecule catalysts. A high-valent iron oxo species, compound I, has been identified as the key intermediate. ${ }^{12}$ The biocatalytic repertoire of P450s has been expanded through directed evolution to include the ability to

generate and transfer abiotic nitrene and carbene intermediates. ${ }^{13}$ We and Fasan engineered $\mathrm{P} 450$ s to catalyze $\mathrm{C}-\mathrm{H}$ amination via sulfonyl nitrene intermediates leading to the formation of diverse sulfonamides. ${ }^{14}$ In spite of the prevalence and fundamental importance of aliphatic primary amines in the biological world, however, $\mathrm{C}\left(s p^{3}\right)-\mathrm{H}$ primary amination is unknown in biology.

A
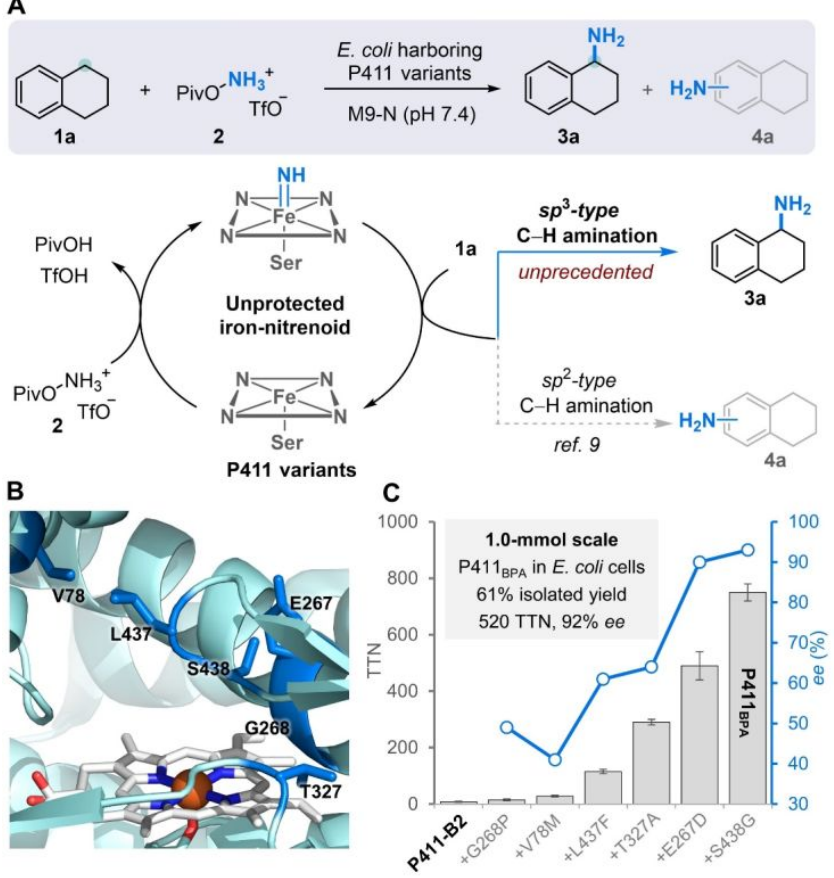

Figure 1. Enzymatic primary amination of benzylic $\mathrm{C}\left(s p^{3}\right)-\mathrm{H}$ bonds. (A) Reaction scheme of benzylic $\mathrm{C}\left(s p^{3}\right)-\mathrm{H}$ primary amination (Piv, pivaloyl, Tf, trifluoromethanesulfonyl). (B) Crystal structure of a variant (PDB ID: 5UCW) closely related to P411-B2 (Section VIII in Supporting Information), with mutated residues marked in blue. ${ }^{14 \mathrm{~d}}$ (C) Evolutionary trajectory of benzylic $\mathrm{C}-\mathrm{H}$ primary aminase $\left(\mathrm{P} 411_{\mathrm{BPA}}\right)$ for the synthesis of benzylic amine 3a and the scale-up reaction. $\mathrm{P} 411_{\mathrm{BPA}}$ was evolved through six rounds of SSM and screening from P411-B2 (Table S2). Indicated mutations are relative to P411-B2. Unless otherwise noted, reaction conditions were as follows: P411 variants in E. coli whole cells [optical density at $600 \mathrm{~nm}\left(\mathrm{OD}_{600}\right)=16$ ], $2.0 \mathrm{mM}$ substrate 1a, 4.0 $\mathrm{mM}$ substrate 2, $2.5 \mathrm{vol} \% \mathrm{EtOH}$ in $\mathrm{M} 9-\mathrm{N}$ (pH 7.4) buffer, $800 \mu \mathrm{L}$ reaction volume at $10^{\circ} \mathrm{C}$ under anaerobic conditions for $12 \mathrm{~h}$. The enantiomeric excess (ee) for P411-B2 was not determined due to the low yield. See the Supporting Information for further details of the scale-up reaction.

Here we addressed this challenge by directed evolution of a P450 from Bacillus megaterium ( $\left.\mathrm{P} 450_{\mathrm{BM} 3}\right)$, which natively catalyzes 
$\mathrm{C}\left(s p^{3}\right)-\mathrm{H}$ hydroxylation of fatty acids. We hypothesized that a high-valent unprotected iron-nitrenoid intermediate would allow for direct $\mathrm{C}\left(s p^{3}\right)-\mathrm{H}$ primary amination, a process analogous to $\mathrm{C}-$ $\mathrm{H}$ hydroxylation through compound $\mathrm{I}$. This iron-nitrenoid intermediate was demonstrated recently by us to enable aminohydroxylation of styrenyl olefins in an engineered cytochrome $c .{ }^{15}$ Considering the highly tunable activities of $\mathrm{P}_{450} 0_{\mathrm{BM} 3}$ for $\mathrm{C}\left(s p^{3}\right)-\mathrm{H}$ functionalization conferred by the protein scaffold, ${ }^{12 a}, 13$ we envisioned that directed evolution could divert and subsequently amplify the reactivity of the unprotected ironnitrenoid species to primary amination of $\mathrm{C}\left(s p^{3}\right)-\mathrm{H}$ bonds. For this investigation we focused on engineered $\mathrm{P} 450_{\mathrm{BM} 3}$ variants that have the iron-coordinating cysteine residue replaced by serine (cytochrome 'P411s'). Substitution of the axial ligand increased the FeIII/FeII reduction potential and enabled the resulting P411s to perform $\mathrm{C}-\mathrm{H}$ functionalization under physiological conditions without additional reductants. ${ }^{16}$

We chose tetrahydronaphthalene $\mathbf{1 a}$ as the model substrate to test in a reaction with the putative iron-nitrenoid generated from hydroxylamine ester 2 (Figure 1A). Although $\mathrm{C}\left(s p^{2}\right)-\mathrm{H}$ primary amination of substrate 1a and its analogues is well established in synthetic chemistry, ${ }^{9}$ primary amination of benzylic $\mathrm{C}\left(s p^{3}\right)-\mathrm{H}$ bonds remains unknown. Indeed, test reactions of $\mathbf{1 a}$ and $\mathbf{2}$ with free heme only produced $\mathrm{C}\left(s p^{2}\right)-\mathrm{H}$ primary amination product $\mathbf{4 a}$ (Table S1). The transformation was then evaluated with a panel of $\mathrm{P} 411$ variants derived from $\mathrm{P} 450_{\mathrm{BM} 3}$. The enzymes were expressed and screened in whole Escherichia coli cells. To suppress dioxygen inhibition, the reactions were performed under anaerobic conditions. A variant named P411-B2, previously engineered for benzylic $\mathrm{C}-\mathrm{H}$ amination via a sulfonyl nitrene, ${ }^{14 \mathrm{~d}}$ was identified to produce the desired primary benzylic amine 3a with 8 total turnover number (TTN). Side product 4 a resulting from $\mathrm{C}\left(s p^{2}\right)-\mathrm{H}$ primary amination was also detected, in a negligible amount $(<1$ TTN). These findings provided a starting point to test our hypothesis that protein engineering could divert and amplify the reactivity of the putative unprotected iron-nitrenoid to $\mathrm{C}\left(s p^{3}\right)-\mathrm{H}$ primary amination.

Variant P411-B2 was chosen as the starting template for directed evolution of an efficient benzylic $C-H$ primary aminase $\left(\mathrm{P} 411_{\mathrm{BPA}}\right)$. Sequential rounds of site-saturation mutagenesis (SSM) and screening were performed to improve catalytic activity and enantioselectivity for the synthesis of benzylic amine 3a. We referred to the crystal structure of a related P411 variant, ${ }^{14 \mathrm{~d}}$ and mainly chose amino acids proximal to the heme and/or residing on flexible loops for mutagenesis (Figure 1B). In each round of SSM, enzyme libraries were generated and screened by HPLC for product formation in 96-well plates in the form of whole-cell catalysts Four rounds of SSM and screening introduced mutations G268P, $\mathrm{V} 78 \mathrm{M}, \mathrm{L} 437 \mathrm{~F}$, and T327A, leading to an increase of ee to $64 \%$ and a 36-fold improvement of TTN to 290 (Figure 1C). Subsequent rounds introduced mutations E267D and S438G, leading to final variant $\mathrm{P} 411_{\mathrm{BPA}}$ and further boosting ee to $93 \%$ and TTN to 750 (Table S2). The formation of side product 4 remained negligible during directed evolution. Notably, the HPLC yield of 3a in reactions at analytical scale was as high as $85 \%$, and primary amine 3a could be isolated in $61 \%$ yield and with $92 \%$ ee by using simple acid-base extraction (1.0 mmol reaction scale). Although the biocatalytic process is scalable, the enzymes are sensitive to substrate concentration and higher concentration of hydroxylamine ester 2 usually leads to a decreased yield.

With $\mathrm{P} 411_{\mathrm{BPA}}$ in hand, we evaluated the substrate scope of alkanes, systematically targeting primary, secondary, and tertiary benzylic $\mathrm{C}-\mathrm{H}$ bonds for primary $\mathrm{C}-\mathrm{H}$ amination (Figure 2). For cyclic substrates bearing secondary benzylic $\mathrm{C}-\mathrm{H}$ bonds, ring sizes ranging from four to six members were well tolerated, affording primary amines 3a-3c. Linear substrates with structurally and electronically diverse aryl groups proved to be compatible and delivered amines 3d-3l with excellent enantioselectivity. In addition to secondary benzylic $\mathrm{C}-\mathrm{H}$ bonds $(\mathbf{3 d}-\mathbf{3 j})$, primary benzylic $\mathrm{C}-\mathrm{H}$ bonds $(\mathbf{3 i}-\mathbf{3 l})$ and tertiary benzylic $\mathrm{C}-\mathrm{H}$ bonds $(\mathbf{3 k})$ were also suitable with varying levels of efficiency and regioselectivity, highlighting the generality of this enzymatic transformation. Reaction at secondary and tertiary benzylic $\mathrm{C}-\mathrm{H}$ bonds was more favorable than at their primary counterparts, as demonstrated by products $\mathbf{3 i}, \mathbf{3} \mathbf{j}$, and $\mathbf{3 k}$. Amination of larger substrates than those shown here or substrates with heteroatoms typically occurred with diminished efficiency, and further directed evolution based on $\mathrm{P} 411_{\mathrm{BPA}}$ may be required for such substrates (Figure S1).
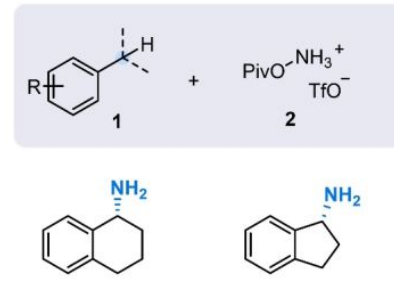

3a, $85 \%$ yield 580 TTN, $93 \%$ ee

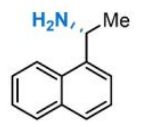

$3 e, 75 \%$ yield 520 TTN, $92 \%$ ee

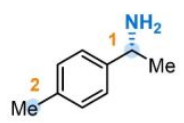

$3 i^{a}{ }^{a} 48 \%$ yield

3.1:1 r.r. (1:2)

500 TTN, $88 \%$ ee

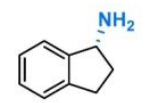

3b, $74 \%$ yield 510 TTN, 65\% ee

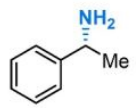

$3 f, 30 \%$ yield 210 TTN, $90 \%$ ee

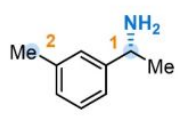

$3 \mathrm{j},{ }^{a} 73 \%$ yield

3.9:1 r.r. (1:2)

750 TTN, $96 \%$ ee

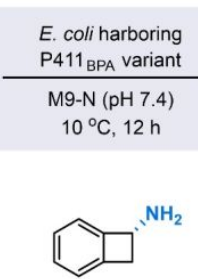

3c, $18 \%$ yield 120 TTN, 95\% ee

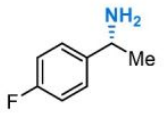

$3 \mathrm{~g}, 44 \%$ yield 300 TTN, $89 \%$ ee

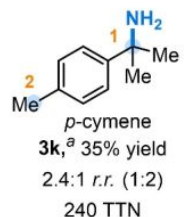

240 TTN
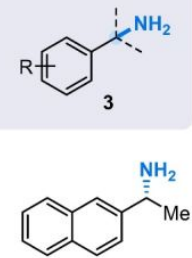

$3 d, 38 \%$ yield 210 TTN, 93\% ee

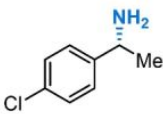

$3 \mathrm{~h}, 46 \%$ yield 310 TTN, $82 \%$ ee
Figure 2. Scope of benzylic amine products. Experiments were performed at analytical scale using enzyme-expressing $E$. coli cells resuspended to $\mathrm{OD}_{600}=16$ or 24 in $\mathrm{M} 9-\mathrm{N}$ medium ( $\mathrm{pH} 7.4$ ), 2.0 $\mathrm{mM}$ substrate 1, $4.0 \mathrm{mM}$ substrate 2, $2.5 \mathrm{vol} \% \mathrm{EtOH}$, and $800 \mu \mathrm{L}$ reaction volume at $10{ }^{\circ} \mathrm{C}$ under anaerobic conditions for 12 hours(Table S3). Regioisomeric ratio (r.r.) indicates the mole ratio of major product to combined minor regioisomers. Yields were quantified by HPLC based on the calibration curve of the corresponding reference products. ${ }^{a}$ Yields and TTNs were calculated based on all regioisomers.

Having achieved primary amination of benzylic $\mathrm{C}-\mathrm{H}$ bonds, we next asked whether the enzymes could aminate other types of $\mathrm{C}\left(s p^{3}\right)-\mathrm{H}$ bonds, particularly in the presence of sensitive olefins. With hydroxylamine derivatives as nitrogen sources and smallmolecule catalysts, alkene substrates were reported to undergo olefin functionalization. ${ }^{17}$ As expected, we observed only amino alcohol $\mathbf{7 a}$ in the reaction of model substrate $\mathbf{5} \mathbf{a}$ and hydroxylamine 2 with free heme as the catalyst (Table S1). Enzymes, however, often feature chemoselectivity in biochemical processes that can be tuned by protein engineering. ${ }^{18}$ Therefore, we envisioned that appropriate engineering of $\mathrm{P} 411_{\mathrm{BPA}}$-related enzymes would enable selective functionalization of allylic $\mathrm{C}-\mathrm{H}$ bonds while minimizing the undesired olefin side reactions. Screening revealed that P411 $1_{\mathrm{BPA}}$-related variants had the desired allylic $\mathrm{C}-\mathrm{H}$ primary amination activity (Figure 3A). Byproduct $7 \mathbf{a}$ was only formed in trace amounts (Table S4), and anilines resulting from $\mathrm{C}\left(s p^{2}\right)-\mathrm{H}$ primary amination were not observed. Starting from an intermediate variant $\mathrm{P} 411_{\mathrm{BPA}}$, having five mutations from $\mathrm{P} 411-\mathrm{B} 2$, we performed two rounds of SSM and screening to generate allylic 
$C-H$ primary aminase $\left(\mathrm{P} 411_{\mathrm{APA}}\right)$ with two additional mutations (N395R, S438A). P411 $1_{\mathrm{APA}}$ is exceptionally efficient and selective (3930 TTN, 93\% HPLC yield, and 94\% ee), and the enzymatic process is easily scalable, with $75 \%$ isolated yield $(1.0 \mathrm{mmol}$ reaction scale).

$\mathrm{P} 411_{\mathrm{APA}}$ is capable of functionalizing primary, secondary, and tertiary allylic $\mathrm{C}-\mathrm{H}$ bonds with a broad substrate scope (Figure 3B). For styrene-type substrates bearing secondary allylic $\mathrm{C}-\mathrm{H}$ bonds, phenyl groups with varying substituents were tolerated well to afford allylic amines $\mathbf{6 a}-\mathbf{6 g}$ with excellent activity and enantioselectivity. In the presence of primary benzylic $\mathrm{C}-\mathrm{H}$ bonds, allylic $\mathrm{C}-\mathrm{H}$ bonds were functionalized with complete regioselectivity $(\mathbf{6 e - 6 g )}$. Substrates with heterocyclic substituents such as thiophenyl (6h) and longer aliphatic substituents (6i) also proved to be suitable. Single regioisomer $\mathbf{6 j}$ was exclusively afforded, indicating $\mathrm{P} 411_{\mathrm{APA}}$ can discriminate between highly similar secondary allylic $\mathrm{C}-\mathrm{H}$ bonds. Tertiary and primary allylic $\mathrm{C}-\mathrm{H}$ bonds could also be aminated efficiently to give products $6 \mathbf{k}$ and 61. Notably, aromatic groups on the alkene moiety are not necessary for allylic $\mathrm{C}-\mathrm{H}$ amination activity, and products $\mathbf{6 m - 6} \mathbf{p}$ were successfully synthesized. For substrates with different types of reactive $\mathrm{C}-\mathrm{H}$ bonds, $\mathrm{P} 411_{\mathrm{APA}}$ exhibits high levels of regioselectivity. While 2-hexene gave a mixture of regioisomers (6n), single regioisomers were observed for other alkenes with up to four sets of allylic $\mathrm{C}-\mathrm{H}$ bonds $(\mathbf{3 o}, \mathbf{3 p})$, such as $\alpha$-terpinene. Although the regioselectivity between secondary and primary $\mathrm{C}-\mathrm{H}$ bonds is dependent on substrate patterns (6n, 6p), P411 1 APA exclusively functionalized primary $\mathrm{C}-\mathrm{H}$ bonds over weaker tertiary $\mathrm{C}-\mathrm{H}$ bonds $(6 \mathbf{6}, 6 \mathbf{6 p})$, which is contrary to the regioselectivity of P $411_{\mathrm{BPA}}$ (3k). Similar to P411 $1_{\mathrm{BPA}}$, further directed evolution of $\mathrm{P} 411_{\mathrm{APA}}$ may be required for efficient functionalization of terminal or larger alkene substrates, especially complex natural products (Figure S1).

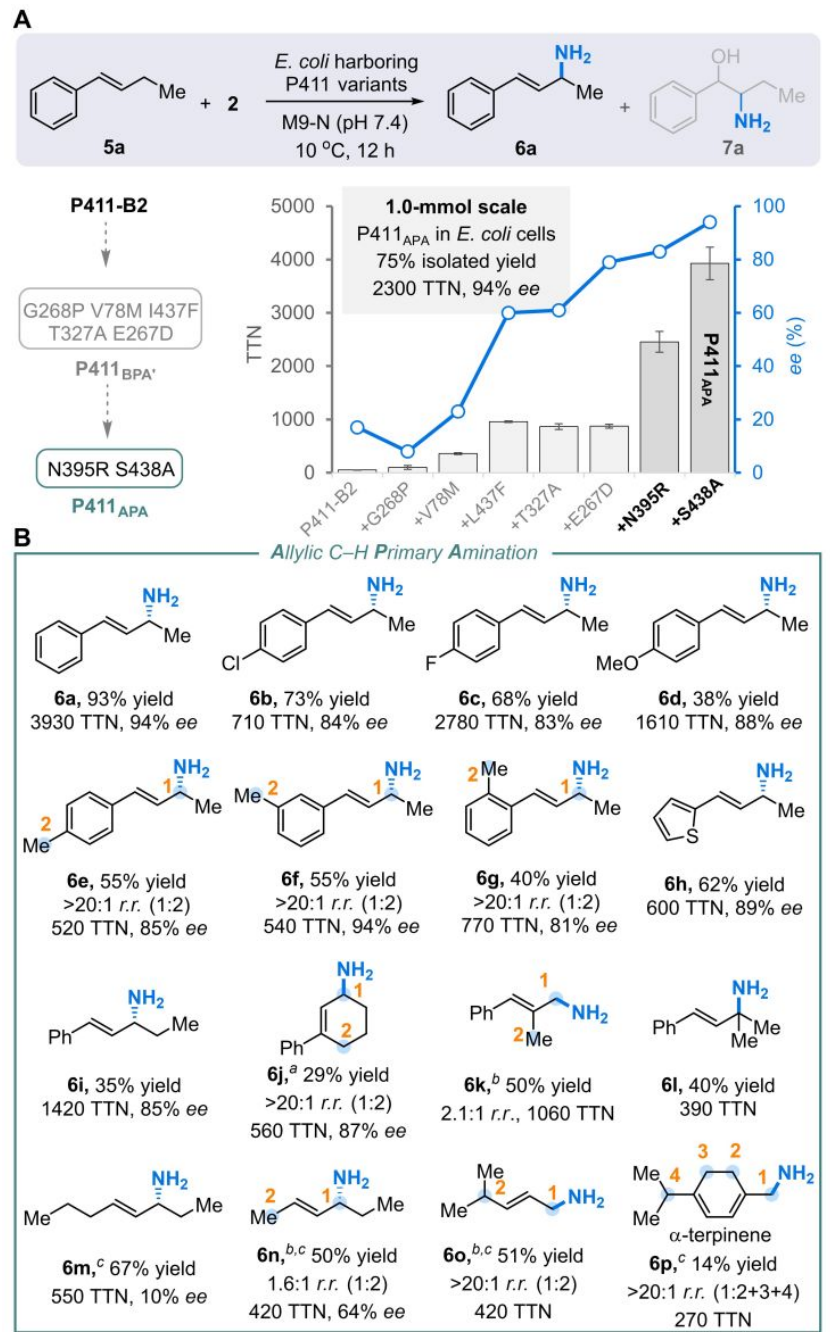

Figure 3. Engineering enzymes for allylic $\mathrm{C}-\mathrm{H}$ primary amination and the substrate scope. (A) Evolutionary trajectory of allylic $\mathrm{C}-\mathrm{H}$ primary aminase $\left(\mathrm{P} 411_{\mathrm{APA}}\right)$ for the synthesis of allylic amine $\mathbf{6 a}$ and the scale-up reaction. $\mathrm{P} 411_{\mathrm{APA}}$ was evolved through two more rounds of SSM and screening starting from an intermediate benzylic $\mathrm{C}-\mathrm{H}$ aminase having five mutations with respect to $\mathrm{P} 411$ B2 (Table S4). The indicated mutations are relative to P411-B2. (B) Substrate scope of allylic $\mathrm{C}-\mathrm{H}$ primary amination (Table S5). Yields were quantified by HPLC based on the calibration curve of the corresponding reference products. ${ }^{a}$ Absolute configuration of 6j could not be determined. ${ }^{b}$ Yields and TTNs were calculated based on all regioisomers. ${ }^{c}$ Products were characterized and quantified by their benzoyl-protected amines.

In conclusion, we have engineered $C\left(s p^{3}\right)-H$ primary aminases that constitute a general platform for selective primary amination of primary, secondary, and tertiary $\mathrm{C}-\mathrm{H}$ bonds at benzylic and allylic positions. These laboratory-evolved enzymes provide a new approach to accessing aliphatic primary amines with high chemoselectivity, regioselectivity, and enantioselectivity. Considering the fundamental roles of primary amines in the biological world and the natural occurrence and biocompatibility of hydroxylamine derivatives, we anticipate that these new, fully genetically-encoded enzymes will provide a starting point to extend or even reformulate currently mapped nitrogen metabolism. Such activities may, in fact, already exist in nature, whose vast catalytic capabilities have only been partially explored. Further elucidation of the catalytic mechanism and characterization of the key 
intermediate would be valuable to generalize this process and inspire the design of corresponding small-molecule catalysts.

\section{ASSOCIATED CONTENT}

\section{Supporting Information}

Materials, experimental methods, and compound characterization data, including Tables S1-S6 and Figure S1.

\section{AUTHOR INFORMATION}

\section{Corresponding Author}

*frances@cheme.caltech.edu

\section{ORCID}

Zhi-Jun Jia: 0000-0002-5143-4875

Shilong Gao: 0000-0003-2808-6283

Frances H. Arnold: 0000-0002-4027-364X

\section{Notes}

Caltech has filed a provisional patent application.

\section{ACKNOWLEDGMENT}

This work is supported by the National Science Foundation (NSF) Division of Molecular and Cellular Biosciences (grant MCB1513007) and the Joseph J. Jacobs Institute for Molecular Engineering for Medicine. Z.-J.J. acknowledges support from Deutsche Forschungsgemeinschaft (JI 289/1-1). We thank S. Brinkmann-Chen, D. C. Miller, N. P. Dunham, S. Athavale, X. Huang, Y. Yang and K. Chen for helpful discussions and comments on the manuscript; S. Athavale for reproduction of key experiments; and The Caltech Center for Catalysis and Chemical Synthesis for analytical support.

\section{REFERENCES}

(1) (a) Hili, R.; Yudin, A. K. Making Carbon-Nitrogen Bonds in Biological and Chemical Synthesis. Nat. Chem. Biol. 2006, 2, 284 287. (b) Vitaku, E.; Smith, D. T.; Njardarson, J. T. Analysis of the Structural Diversity, Substitution Patterns, and Frequency of Nitrogen Heterocycles among U.S. FDA Approved Pharmaceuticals. J. Med. Chem. 2014, 57, 10257-10274.

(2) Amino Group Chemistry: From Synthesis to the Life Sciences; Ricci, A., Ed.; Wiley-VCH: Weinheim, Germany, 2008.

(3) Legnani, L.; Bhawal, B. N.; Morandi, B. Recent Developments in the Direct Synthesis of Unprotected Primary Amines. Synthesis 2017, 49, 776-789.

(4) Gross, T.; Seayad, A. M.; Ahmad, M.; Beller, M. Synthesis of Primary Amines: First Homogeneously Catalyzed Reductive Amination with Ammonia. Org. Lett. 2002, 4, 2055-2058.

(5) (a) Hartwig, J. F. Evolution of a Fourth Generation Catalyst for the Amination and Thioetherification of Aryl Halides. Acc. Chem. Res. 2008, 41, 1534-1544. (b) Surry, D. S.; Buchwald, S. L. Biaryl Phosphane Ligands in Palladium-Catalyzed Amination. Angew. Chem, Int. Ed. 2008, 47, 6338-6361.

(6) Park, Y.; Kim, Y.; Chang, S. Transition Metal-Catalyzed C-H Amination: Scope, Mechanism, and Applications. Chem. Rev. 2017, 117, 9247-9301.

(7) (a) Romero, N. A.; Margrey, K. A.; Tay, N. E.; Nicewicz, D. A. Site-Selective Arene $\mathrm{C}-\mathrm{H}$ Amination via Photoredox Catalysis. Science 2015, 349, 1326-1330. (b) Zheng, Y.-W.; Chen, B.; Ye, P.; Feng, K.; Wang, W.; Meng, Q.-Y.; Wu, L.-Z.; Tung, C.-H. Photocatalytic Hydrogen-Evolution Cross-Couplings: Benzene CH Amination and Hydroxylation. J. Am. Chem. Soc. 2016, 138, 10080-10083.
(8) Morofuji, T.; Shimizu, A.; Yoshida, J.-I. Electrochemical C-H Amination: Synthesis of Aromatic Primary Amines via $\mathrm{N}$ Arylpyridinium Ions. J. Am. Chem. Soc. 2013, 135, 5000-5003.

(9) (a) Peng, J.; Chen, M.; Xie, Z.; Luo, S.; Zhu, Q. CopperMediated $\mathrm{C}\left(\mathrm{sp}^{2}\right)-\mathrm{H}$ Amination Using $\mathrm{TMSN}_{3}$ as a Nitrogen Source: Redox-Neutral Access to Primary Anilines. Org. Chem. Front. 2014, 1, 777-781. (b) Tezuka, N.; Shimojo, K.; Hirano, K.; Komagawa, S.; Yoshida, K.; Wang, C.; Miyamoto, K.; Saito, T.; Takita, R.; Uchiyama, M. Direct Hydroxylation and Amination of Arenes via Deprotonative Cupration. J. Am. Chem. Soc. 2016, 138, 9166-9171. (c) Paudyal, M. P.; Adebesin, A. M.; Burt, S. R.; Ess, D. H.; Ma, Z.; Kürti, L.; Falck, J. R. Dirhodium-Catalyzed C-H Arene Amination Using Hydroxylamines. Science 2016, 353, 1144-1147. (d) Legnani, L.; Prina Cerai, G.; Morandi, B. Direct and Practical Synthesis of Primary Anilines through Iron-Catalyzed C-H Bond Amination. ACS Catal. 2016, 6, 8162-8165. (e) Liu, J.; Wu, K.; Shen, T.; Liang, Y.; Zou, M.; Zhu, Y.; Li, X.; Li, X.; Jiao, N. Fe-Catalyzed Amination of (Hetero)Arenes with a RedoxActive Aminating Reagent under Mild Conditions. Chem. Eur. J. 2017, 23, 563-567. (f) Kim, H.; Heo, J.; Kim, J.; Baik, M.-H.; Chang, S. Copper-Mediated Amination of Aryl C-H Bonds with the Direct Use of Aqueous Ammonia via a Disproportionation Pathway. J. Am. Chem. Soc. 2018, 140, 14350-14356. (g) D'Amato, E. M.; Börgel, J.; Ritter, T. Aromatic C-H Amination in Hexafluoroisopropanol. Chem. Sci. 2019, 10, 2424-2428. (h) Anugu, R. R.; Munnuri, S.; Falck, J. R. Picolinate-Directed Arene meta-C-H Amination via $\mathrm{FeCl}_{3}$ Catalysis. J. Am. Chem. Soc. 2020, 142, 5266-5271.

(10) (a) Slabu, I.; Galman, J. L.; Lloyd, R. C.; Turner, N. J., Discovery, Engineering, and Synthetic Application of Transaminase Biocatalysts. ACS Catal. 2017, 7, 8263-8284. (b) Guo, F.; Berglund, P., Transaminase Biocatalysis: Optimization and Application. Green Chem. 2017, 19, 333-360. (c) Zhang, J.; Abidin, M. Z.; Saravanan, T.; Poelarends, G. J., Recent Applications of Carbon-Nitrogen Lyases in Asymmetric Synthesis of Noncanonical Amino Acids and Heterocyclic Compounds. ChemBioChem 2020, DOI: 10.1002/cbic.202000214.

(11) Lewis, J. C.; Coelho, P. S.; Arnold, F. H. Enzymatic Functionalization of Carbon-Hydrogen Bonds. Chem. Soc. Rev. 2011, 40, 2003-2021.

(12) (a) Ortiz de Montellano, P. R. Hydrocarbon Hydroxylation by Cytochrome P450 Enzymes. Chem. Rev. 2010, 110, 932-948. (b) Rittle, J.; Green, M. T. Cytochrome P450 Compound I: Capture, Characterization, and C-H Bond Activation Kinetics. Science 2010, 330, 933-937.

(13) (a) Brandenberg, O. F.; Fasan, R.; Arnold, F. H. Exploiting and Engineering Hemoproteins for Abiological Carbene and Nitrene Transfer Reactions. Curr. Opin. Biotechnol. 2017, 47, 102111. (b) Fasan, R.; Kan, S. B.; Zhao, H. A Continuing Career in Biocatalysis: Frances H. Arnold. ACS Catal. 2019, 9, 9775-9788. (c) Chen, K.; Arnold, F. H. Engineering New Catalytic Activities in Enzymes. Nat. Catal. 2020, 3, 203-213. (d) Singh, R.; Kolev, J. N.; Sutera, P. A.; Fasan, R. Enzymatic C( $\left.\mathrm{sp}^{3}\right)-\mathrm{H}$ Amination: P450Catalyzed Conversion of Carbonazidates into Oxazolidinones. ACS Catalysis 2015, 5, 1685-1691. (e) Key, H. M.; Dydio, P.; Clark, D. S.; Hartwig, J. F. Abiological Catalysis by Artificial Haem Proteins Containing Noble Metals in Place of Iron. Nature 2016, 534, 534 537. (f) Dydio, P.; Key, H. M.; Hayashi, H.; Clark, D. S.; Hartwig, J. F. Chemoselective, Enzymatic C-H Bond Amination Catalyzed by a Cytochrome P450 Containing an $\operatorname{Ir}(\mathrm{Me})$-PIX Cofactor. J. Am. Chem. Soc. 2017, 139, 1750-1753.

(14) (a) McIntosh, J. A.; Coelho, P. S.; Farwell, C. C.; Wang, Z. J.; Lewis, J. C.; Brown, T. R.; Arnold, F. H. Enantioselective Intramolecular $\mathrm{C}-\mathrm{H}$ Amination Catalyzed by Engineered Cytochrome P450 Enzymes in vitro and in vivo. Angew. Chem, Int. Ed. 2013, 52, 9309-9312. (b) Hyster, T. K.; Farwell, C. C.; Buller, A. R.; McIntosh, J. A.; Arnold, F. H. Enzyme-Controlled Nitrogen- 
Atom Transfer Enables Regiodivergent C-H Amination. J. Am. Chem. Soc. 2014, 136, 15505-15508. (c) Singh, R.; Bordeaux, M.; Fasan, R. P450-Catalyzed Intramolecular $\mathrm{sp}^{3} \mathrm{C}-\mathrm{H}$ Amination with Arylsulfonyl Azide Substrates. ACS Catalysis 2014, 4, 546-552. (d) Prier, C. K.; Zhang, R. K.; Buller, A. R.; Brinkmann-Chen, S.; Arnold, F. H. Enantioselective, Intermolecular Benzylic $\mathrm{C}-\mathrm{H}$ Amination Catalysed by an Engineered Iron-Haem Enzyme. Nat. Chem. 2017, 9, 629-634. (e) Yang, Y.; Cho, I.; Qi, X.; Liu, P.; Arnold, F. H. An Enzymatic Platform for the Asymmetric Amination of Primary, Secondary and Tertiary $\mathrm{C}\left(s p^{3}\right)-\mathrm{H}$ Bonds. Nat. Chem. 2019, 11, 987-993.

(15) Cho, I.; Prier, C. K.; Jia, Z.-J.; Zhang, R. K.; Görbe, T.; Arnold, F. H. Enantioselective Aminohydroxylation of Styrenyl Olefins Catalyzed by an Engineered Hemoprotein. Angew. Chem, Int. Ed. 2019, 58, 3138-3142.

(16) Coelho, P. S.; Wang, Z. J.; Ener, M. E.; Baril, S. A.; Kannan, A.; Arnold, F. H.; Brustad, E. M. A Serine-Substituted P450 Catalyzes Highly Efficient Carbene Transfer to Olefins in vivo. Nat. Chem. Biol. 2013, 9, 485-487.

(17) (a) Jat, J. L.; Paudyal, M. P.; Gao, H. Y.; Xu, Q. L.; Yousufuddin, M.; Devarajan, D.; Ess, D. H.; Kurti, L.; Falck, J. R.
Direct Stereospecific Synthesis of Unprotected N-H and N-Me Aziridines from Olefins. Science 2014, 343, 61-65. (b) Legnani, L.; Morandi, B. Direct Catalytic Synthesis of Unprotected 2Amino-1-Phenylethanols from Alkenes by Using Iron(II) Phthalocyanine. Angew. Chem. Int. Ed. 2016, 55, 2248-2251. (c) Ma, Z.; Zhou, Z.; Kürti, L. Direct and Stereospecific Synthesis of $N$-H and $N$-Alkyl Aziridines from Unactivated Olefins Using Hydroxylamine-O-Sulfonic Acids. Angew. Chem, Int. Ed. 2017, 56, 9886-9890. (d) Legnani, L.; Prina-Cerai, G.; Delcaillau, T.; Willems, S.; Morandi, B. Efficient Access to Unprotected Primary Amines by Iron-Catalyzed Aminochlorination of Alkenes. Science 2018, 362, 434-439. (e) Zhou, Z.; Cheng, Q.-Q.; Kürti, L. AzaRubottom Oxidation: Synthetic Access to Primary $\alpha$ Aminoketones. J. Am. Chem. Soc. 2019, 141, 2242-2246. (f) Cheng, Q.-Q.; Zhou, Z.; Jiang, H.; Siitonen, J. H.; Ess, D. H.; Zhang, X.; Kürti, L. Organocatalytic Nitrogen Transfer to Unactivated Olefins via Transient Oxaziridines. Nat. Catal. 2020, 3, 386-392.

(18) Benkovic, S. J.; Hammes-Schiffer, S. A Perspective on Enzyme Catalysis. Science 2003, 301, 1196-1202. 
SYNOPSIS TOC

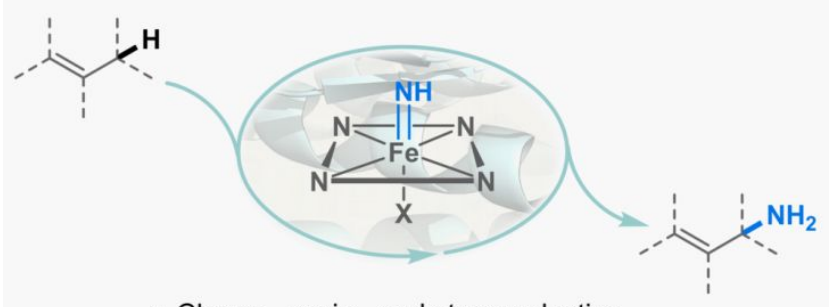

- Chemo-, regio-, and stereoselective

- Up to $93 \%$ yield, 3930 TTN, and $96 \%$ ee 
A<smiles>c1ccc2c(c1)CCCC2</smiles>

$1 a$

\section{$+\mathrm{PivO}^{-} \mathrm{NH}_{3}{ }^{+}$
$\mathrm{TfO}^{-}$}

2

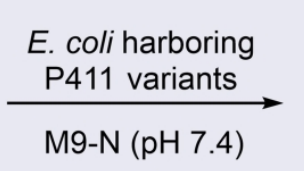

M9-N (pH 7.4)

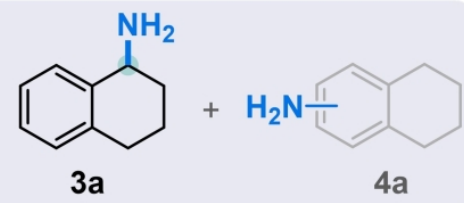

$4 a$

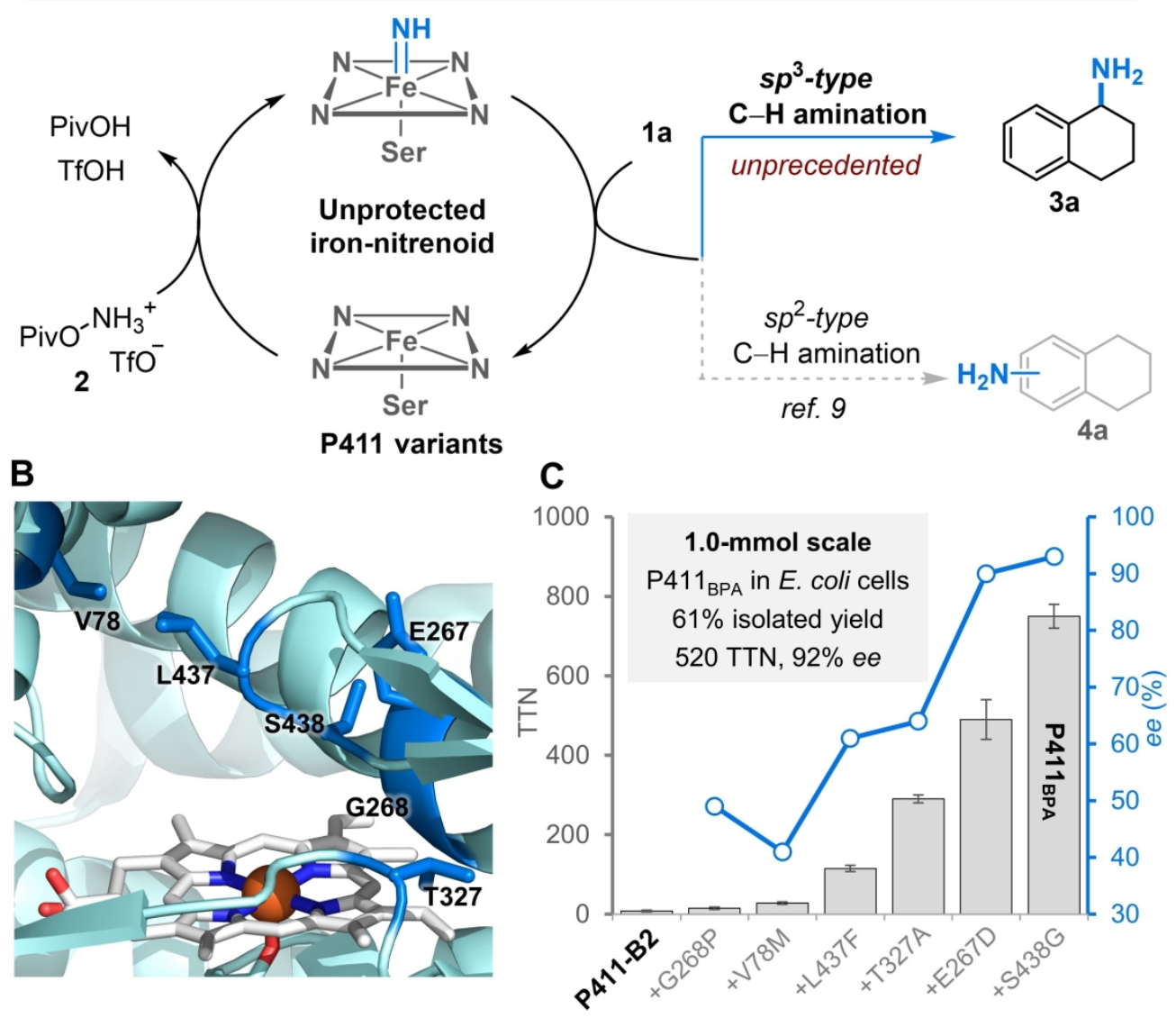

Figure 1. Enzymatic primary amination of benzylic $\mathrm{C}\left(s p^{3}\right)-\mathrm{H}$ bonds. (A) Reaction scheme of benzylic $\mathrm{C}\left(s p^{3}\right)-\mathrm{H}$ primary amination (Piv, pivaloyl). (B) Crystal structure of a variant (PDB ID: 5UCW) closely related to P411-B2 (the sequence of P411-B2 can be found in the Supporting Information), with mutated residues marked in blue. ${ }^{14 d}$ (C) Evolutionary trajectory of benzylic $C-H$ primary aminase (P411 $1_{\mathrm{BPA}}$ ) for the synthesis of benzylic amine $\mathbf{3 a}$ and the scale-up reaction. P411 BPA was evolved through six rounds of SSM and screening from P411-B2 (Table S2). Indicated mutations are relative to P411-B2. Unless otherwise noted, reaction conditions were as follows: P411 variants in E. coli whole cells [optical density at $600 \mathrm{~nm}$ $\left.\left(\mathrm{OD}_{600}\right)=16\right], 2.0 \mathrm{mM}$ substrate $\mathbf{1 a}, 4.0 \mathrm{mM}$ substrate 2, $2.5 \mathrm{vol} \% \mathrm{EtOH}$ in M9-N (pH 7.4) buffer, $800 \mu \mathrm{L}$ reaction volume at $10^{\circ} \mathrm{C}$ under anaerobic conditions for $12 \mathrm{~h}$. The enantiomeric excess (ee) for P411-B2 was not determined due to the low yield. See the Supporting Information for further details of the scale-up reaction. 


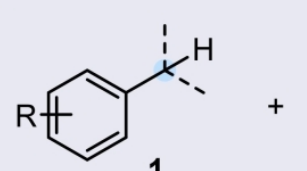

1
$\mathrm{PivO}_{2}^{-\mathrm{NH}_{3}{ }^{+}} \mathrm{TfO}^{-}$<smiles>N[C]1CCc2ccccc21</smiles>

3b, $74 \%$ yield 510 TTN, $65 \%$ ee<smiles>N[C@H]1CCCc2ccccc21</smiles>

$3 a, 85 \%$ yield 580 TTN, 93\% ee<smiles>C[C@H](N)c1cccc2ccccc12</smiles>

3 e, $75 \%$ yield 520 TTN, 92\% ee<smiles>Cc1ccc([C@@H](C)N)cc1</smiles>

$3 i^{a} 48 \%$ yield

3.1:1 r.r. (1:2)

500 TTN, $88 \%$ ee<smiles>C[C@H](N)c1ccccc1</smiles>

3f, $30 \%$ yield 210 TTN, 90\% ee<smiles>N[C]1Cc2ccccc21</smiles>

$3 c, 18 \%$ yield 120 TTN, 95\% ee 3

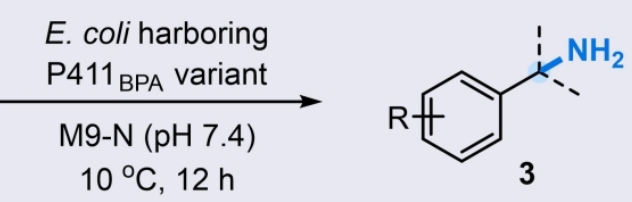<smiles>C[C@H](N)c1ccc2ccccc2c1</smiles>

3d, 38\% yield 210 TTN, 93\% ee

Figure 2. Scope of benzylic amine products. Experiments were performed at analytical scale using enzymeexpressing $E$. coli cells resuspended to $\mathrm{OD}_{600}=16$ or 24 in M9-N medium (pH 7.4), $2.0 \mathrm{mM}$ substrate $1,4.0$ $\mathrm{mM}$ substrate 2, $2.5 \mathrm{vol} \% \mathrm{EtOH}$, and $800 \mu \mathrm{L}$ reaction volume at $10{ }^{\circ} \mathrm{C}$ under anaerobic conditions for 12 hours. See Table $\mathbf{S} 3$ for further details. Regioisomeric ratio (r.r.) indicates the mole ratio of major product to combined minor regioisomers. Yields were quantified by HPLC based on the calibration curve of the corresponding reference products. ${ }^{a}$ Yields and TTNs were calculated based on all regioisomers.

$$
769 \times 776 \mathrm{~mm}(96 \times 96 \mathrm{DPI})
$$


A

Figure 3. Engineering enzymes for allylic $\mathrm{C}-\mathrm{H}$ primary amination and the substrate scope. (A) Evolutionary trajectory of allylic $\mathrm{C}-\mathrm{H}$ primary aminase (P411 APA) for the synthesis of allylic amine 6 a and the scale-up reaction. P411 APA was evolved through two more rounds of SSM and screening starting from an intermediate benzylic $\mathrm{C}-\mathrm{H}$ aminase having five mutations with respect to P411-B2 (Table S4). The indicated mutations are relative to P411-B2. (B) Substrate scope of allylic C-H primary amination. See Table S5 for more details. Yields were quantified by HPLC based on the calibration curve of the corresponding reference products. ${ }^{a}$ The absolute configuration of $\mathbf{6 j}$ could not be determined. ${ }^{b}$ Yields and TTNs were calculated based on all regioisomers. c Products were characterized and quantified by their benzoyl-protected amines.

$158 \times 260 \mathrm{~mm}(300 \times 300$ DPI $)$ 